\title{
Notes
}

\section{Porphyry's Lines in the To Ablabius by Gregory of Nyssa}

\author{
Dmitry Biriukov \\ National Research University Higher School of Economics (HSE), \\ St. Petersburg \\ dbirjuk@gmail.com
}

\begin{abstract}
I show that Gregory of Nyssa used significant points from a passage of Porphyry's Isagoge while developing his doctrine of the general and the particular.
\end{abstract}

\section{Keywords}

Gregory of Nyssa - Porphyry - the individual - divisibility - the general - unity nature - monad

In* the treatise To Ablabius. On Not Three Gods Gregory of Nyssa displays a number of peculiar ideas. In particular, as a part of his defense against accusations of tritheism (and while using for this purpose the analogy elaborated by the Cappadocians between hypostases of the Trinity and human individuals) Gregory speaks about the use of the plural case applied to a so-called

* This article was prepared within the framework of the Basic Research Program at the National Research University Higher School of Economics (HSE) and supported within the framework of a subsidy by the Russian Academic Excellence Project '5-100'. 
indivisible nature. It corresponds to the species of the thing; and in line with this he contrasts, on the one hand a word usage that is correct in its meaning although is not commonly used, and on the other hand there is a word that is used but not correct in its form. He says that it is not correct to use the word "man" with the meaning of human species in plural, although in colloquial speech such usage is absolutely natural. Instead, the correct usage is that where the word "man" is used as a singular. Gregory states that because the word "man" points to the species, or to the nature, the use of this word in the plural implies the presence of a multitude of natures. It would follow then that human nature is no longer indivisible, something that Gregory regards as absurd ${ }^{1}$.

To elaborate upon his thought Gregory offers the example of calling upon a man. Such an action can be either successful or unsuccessful. The bishop of Nyssa says that if the word used for calling upon a certain man has the meaning of a common nature, then such an action will be unsuccessful. It is only when one calls upon the personal name of the intended individual (which distinguishes him from another man) that one will succeed. This is because the personal name points to the subject, individual, while a common name suggests only a shared nature. In the course of this epistemological reasoning, Gregory allows himself to make certain ontological utterances. A personal name, Gregory says, distinguishes the individual from the many (who partake of the common nature) although the nature of all individuals is the same (i.e. the same human nature, which is actually the only one to be called "man") ${ }^{2}$. Gregory then refines the specifics of hypostases and nature on the basis of the categories countability/divisibility and unity. The hypostases are conformed to

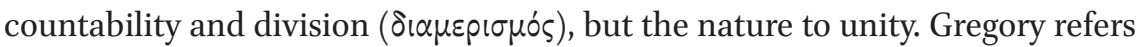
to nature as an indivisible monad, although it is present through multitude (i.e. through individuals), it is one and undivided by those who take part in it. ${ }^{3}$ Later on Gregory gives an example, which is supposed to illustrate what has been said. He states that the words "people," "army," and "counsel" are such that taken in the singular they have the meaning of the plural. This statement can be inspected through the word "man," which itself means something singular - human nature, although what belongs to the human nature is plural (i.e. human individuals, people). Thus, Gregory sums up that it is better to use the term "nature" in the correct way, namely not in the plural but in the singular.

1 Gregory of Nyssa, Ad Abl., Gregorii Nysseni Opera, Vol. III, pars I, Auxilio aliorum virorum doctorum edenda curavit W. Jaeger, Leiden, 1958, p. 40: 5-9.

2 Gregory of Nyssa, Ad Abl., Gregorii Nysseni Opera, Vol. III, pars I, p. 40: 10-23.

3 Gregory of Nyssa, Ad Abl., Gregorii Nysseni Opera, Vol. III, pars I, pp. 40: 24-41: 7. 
And if we cannot use it in such a way in colloquial language, then we must do such differentiation in theological language (and not speak about three divine natures) ${ }^{4}$. Closer to the end of the treatise Gregory comes back to this theme. He again claims that it is incorrect to use the word "nature" to refer to many, and supports his argument declaring that "nature" cannot decrease or increase, although "nature" is perceived in many. Countability, which implies existence in a mode of multitude, is typical only of something individualized, i.e. confined spatially, etc. Something that is not individualized is neither countable, hence it cannot be represented in a mode of multitude. Such is the relation between the nature of gold (as uncountable and not individualized) and concrete golden coins (as countable and possessing individual features). The same argument is applied to human nature. It consists of many individuals, but "man" in them all is the same and one ${ }^{5}$.

As opposed to the previous studies, I believe that the specific philosophical doctrine developed by Gregory in his treatise Ad Ablabium (with some important points discussed in Letter 38 ) is essentially based on Isagoge by Porphyry. In this regard, I discern several trends that were essential for Gregory's specific approach and his use of philosophical language for describing the problem of the relationship between the general and the particular in Ad Ablabium and Letter 38 . The following trends are manifested in the preceding philosophical tradition of Antiquity associated with The Categories and their commentaries: 1) the principle that division corresponds to the particular and individual, while unity corresponds to the species and the natural; 2) the concept of a "the common man" as applied to mankind; 3) the argument of the participation of the individual in general, or of individuals in nature; 4) the principle of the indivisibility of species by the individuals that participate in it; and 5 ) the principle of "the more and the less."

We should start with the last point. When Gregory says in Ad Ablabium that the monad (that is, the nature or species) does not increase with addition and does not reduce with subtraction, ${ }^{6}$ he expresses, in other words, the thought from the passage in his Contra Eunomium I, 1, 173, 2-175, ${ }^{7}$ that human nature is always in the same way present in mankind, although the individual humans belonging to it are born and die in time. The passage reveals a clear

4 Gregory of Nyssa, Ad Abl., Gregorii Nysseni Opera, Vol. III, pars I, p. 41: 7-15.

5 Gregory of Nyssa, Ad Abl., Gregorii Nysseni Opera, Vol. III, pars I, pp. 53: 6-54: 4.

6 Gregory of Nyssa, Ad Abl., Gregorii Nysseni Opera, Vol. III, pars I, pp. 40: 24-41: 7.

7 Gregorii Nysseni opera. Contra Eunomium Libri I et II, pars prior, ed. W. Jaeger, Leiden, 1960, p. 78. 
Aristotelian/Porphyrian context associated with the topic of "the more and the less" in connection with the category of substance. ${ }^{8}$

This same context is manifested in the words of Gregory when he justifies the use of the term "nature" only in the singular and says that nature can neither decrease nor increase. ${ }^{9}$ Gregory's argument in Ad Ablabium and especially in Letter 38 is based on the premise that the particular and the individual correspond to division, while the species and the natural correspond to unity. ${ }^{10}$ This premise also appears in Ad Ablabium, where Gregory explains, "The idea of the hypostases admits of that separation which is made by the peculiar attributes considered in each severally, and when they are combined is presented to us by means of number."11

Here we can see the expression of an important argument of Isagoge where the movement along the genera/species hierarchy towards the more particular is associated with the concept of division, while the movement towards the more common is associated with the concept of unity. As Porphyry explains, the individual is associated with divisibility, while the general is associated with unity. Porphyry speaks about it in the same passage of Isagoge where he addresses another important issue for the kind of philosophy Gregory elaborates in Ad Ablabium and Letter 38 - the subject of the "common man" as applied to the human race. The same passage of Porphyry also contains the Aristotelian concept of the participation of individuals in their natural species which, as we have seen, Gregory also uses in Ad Ablabium. Thus, all these topics may be found in Porphyry in a passage from the second chapter of Isagoge:

So, when we are descending to the most special items, it is necessary to divide and to proceed through a plurality ( $\delta \dot{\alpha} \pi \lambda \hat{\eta} \theta 0 u \varsigma)$, and when we are ascending to the most general items, it is necessary to bring the plurality

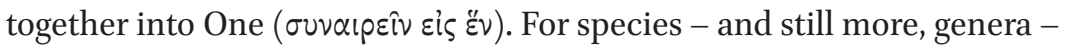

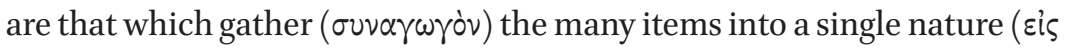
$\mu i \alpha \nu \varphi v(v)$; whereas the particulars or singulars, in contrary fashion, always divide ( $\delta\llcorner\propto\llcorner\rho \varepsilon \hat{\imath})$ the one into a plurality. For by participating in the

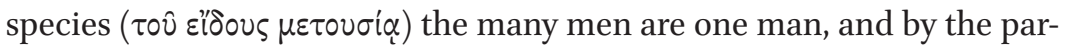
ticulars the one and common (o gis xai xoเvò $)$ ) man is several - for the

8 See: D. Biriukov, "Eunomius and Gregory of Nyssa on the Principle of 'the More and the Less' and Its Application to the Category of Substance," Scr, 14 (2018), pp. 467-474.

9 Gregory of Nyssa, Ad Abl., Gregorii Nysseni Opera, Vol. III, pars I, pp. 53: 6-54: 4.

$10 \quad E p .38$, 4, Saint Basile, Lettres, vol. 1, ed. Y. Courtonne, Paris, 1957, p. 87: 81-91.

11 Gregory of Nyssa, Ad Abl., Gregorii Nysseni Opera, Vol. III, pars I, pp. 40: 24-41: 2. 
singular is always divisive whereas the common is collective and unificatory. ${ }^{12}$

Keeping in mind the fact that Gregory uses these three points from a single passage of the Isagoge while developing his theory of the general and the particular, it can be argued that the Isagoge (and specifically that passage) significantly influenced Gregory's elaboration of principles appearing in his $\mathrm{Ad}$ Ablabium, Letter 38, and other texts of Gregory on the subject.

It seems that Gregory's use of the concept of the monad ( $\mu \circ \alpha_{\alpha}$ ), which is absent from Porphyry's Isagoge can be related to Porphyry's concept of the "common man." Writing about the monad, Gregory must have reformulated the notion of "oneness" from Porphyry, enriching it by the additional connotations associated with an emphasis on the unity and integrity of nature / species.

However, Richard Cross suggests that in this passage of the Isagoge Porphyry elaborates the collective understanding of the universals that implies that species are divided by the individuals. Cross believes that Gregory of Nyssa argues precisely with this notion when he proposes that the monad (that is, the nature or species of the thing) is indivisible by the individuals participating in it. ${ }^{13}$ I believe Cross's understanding of Porphyry is wrong. Cross does not take into account the fact that the positions expressed by Porphyry in the Isagoge do not claim ontological status, but are rather logical exercises as Porphyry clearly states in the beginning of his treatise. ${ }^{14}$ Therefore, in attributing the collective understanding of the universals to Porphyry, Cross unjustifiably "ontologizes" a purely logical discourse. When in his logical framework Porphyry says that the individual divides the unity into multiplicity, this in no way implies that the real unity (species) consists of multiplicity (individuals). It means that if we build up a generic hierarchy in our mind, the higher we ascend along the hierarchy of commonness with our mind, the greater degree of unification we will find in the order of the hierarchy, whereas the lower we descend with our mind, the greater degree of division we will find there. This is the exact meaning of Porphyry's words that the individual is associated with divisibility, while the totality is associated with unification. When Gregory borrows this concept from Porphyry, he follows Porphyry in his statement that the

\footnotetext{
12 Porphyry, Isag. I: Porphyrii Isagoge et in Aristotelis Categorias commentarium, ed. A. Busse (CAG, IV.I), Berlin, 1887, p. 6: 16-23, the translation by J. Barnes, in: Porphyry, Introduction, Translated, with a Commentary, by J. Barnes, Oxford, 2006, p. 7 .

13 R. Cross, "Gregory of Nyssa on Universals," Vigiliae Christianae, 56 (2002), p. 372-410, here 376-379.

14 Porph., Isag. I: Porphyrii Isagoge, p. 1: 8-12.
} 
species are characterized by unity, while the individuals are characterized by division and multiplicity, and this is why the individual/species discourse implies a "conjoined separation and a separated union."15 Yet, neither in the case of Porphyry nor in the case of Gregory does it mean that in reality the species are divided into parts by the individuals, or the collective understanding of a universal (= species). Incidentally, Cross also notes the words about united division and divided unity in Gregory's Letter 38, describing them as paradoxical. However, Cross does not realize that these words mean the same as what Porphyry discusses in the Isagoge II, p. 6, 16-23 (see above), and incorrectly understood them in the sense of the collective meaning of the universals.

Thus, when Gregory uses Porphyry's subject, his theological language manifests the elements of logical discourse. In general, in Ad Ablabium and Letter 38 , Gregory combines epistemological, ontological, and logical discourses.

$15 \quad$ Ep. 38, 4, Saint Basile, Lettres, p. 87: 91. 